\title{
Causal clauses with fordi 'because' in (formal) spoken Danish
}

\section{SUNE GREGERSEN}

This article investigates the form and function of fordi 'because' clauses in formal spoken Danish. The corpus consists of the minutes and video recordings of five debates in the Danish Parliament. It is shown that verb-second (V2) order is much more frequent than verb-third (V3) - indicating that V2 is not only a feature of colloquial spoken language - and that fordi can introduce interrogative clauses (as in fordi hvad handler det om $i$ skrobelige stater? 'because what is it all about in vulnerable states?'). In addition, it is discussed to what extent the choice between $\mathrm{V} 2$ and V3 is predicted by the meaning of the fordi 'because' clause.

KEYWORDS: word order, subordination, Germanic; V2, embedded root phenomena 